\title{
Comparison of the Effect of Quality of Nursing Work Life Dimensions on Turnover Intention in Private Hospitals and Government Hospitals
}

\author{
Azhar $^{1}$, A. Indahwaty $\operatorname{Sidin}^{1}$, Sangkala Rewa ${ }^{2}$ \\ Corresponding Email: azhararsyad88@gmail.com \\ ${ }^{1}$ Hospital Management Department, Faculty of Public Health, Hasanuddin University, \\ Indonesia \\ ${ }^{2}$ Department of Administrative Science, Faculty of Social and Political Sciences, Hasanuddin \\ University, Indonesia \\ Received: December 22, 2021 \\ Received in Revised: January 12, 2022 \\ Accepted: January 30, 2022
}

\begin{abstract}
This study aims to analyze the effect of the dimensions of quality nursing of work life on turnover intention in RSIA Ananda and RSKD Mother and Children Pertiwi. This type of research is a quantitative research using an observational study with a cross sectional study design. The sample in this study were nurses who worked at RSIA Ananda as many as 72 nurses who were representatives of private hospital nurses and nurses who worked at RSKD Mother and Children Pertiwi as many as 70 nurses who were representatives of government hospital nurses. The results showed that there was no statistically significant effect of worklife/homelife dimension on turnover intention at RSIA Ananda $(\mathrm{p}=0.239)$ and RSKDIA Pertiwi ( $\mathrm{p}=0.055)$, there was no statistically significant effect of work design dimension on turnover intention at RSIA Ananda. $(p=0,260)$ and RSKDIA Pertiwi $(p=1,000)$, there was no statistically significant effect of work context dimension on turnover intention at RSIA Ananda ( $\mathrm{p}=0,093)$ and RSKDIA Pertiwi $(\mathrm{p}=1,000)$, there was a statistically significant effect work world dimension on turnover intention at RSIA Ananda $(\mathrm{p}=0.016)$ and there is no statistically significant effect of work world dimension on turnover intention at RSKDIA Pertiwi ( $\mathrm{p}=$ 0.684 ), and work world dimension variables that have an influence on turnover intention at RSIA Ananda ( $\mathrm{p}=0.047)$. It is suggested to the hospital management to review the situation of the nurse's work environment in order to improve the quality of her work life and commitment to the organization in the hospital and to pay more attention to the fulfillment of the nurse's personal needs.
\end{abstract}

Keywords: Quality of Nursing Work Life, Turnover Intention, Nurse

\section{Introduction}

Nurses have a role and function in carrying out their duties. The main task of nurses according to Permenpan No. 25 of 2014 is to carry out nursing service activities which include nursing care, nursing management and community service.

In Indonesia, nurse turnover often occurs in private hospitals, this is because private hospitals are a form of company that has internal rules and guidelines or commitments that do not take into account the elements of cost benefits and cost effectiveness for nurses. On the other hand, the demand for optimal health services for the community requires nurses to work professionally with a high workload. Nurse turnover events will cause a lot of losses for hospitals, both in terms of costs, resources, and employee motivation. Turnover will also cause 
the hospital to lose a number of employees and automatically this loss process must be replaced with new employees to meet the needs of service personnel for patients.

Nurses as the largest health workers should have a good quality of work life so that they can provide quality services to patients (Moradi et al., 2014). Quality of work life of nurses is a term for the balance of personal and professional life which is a continuous effort for most health workers, including nurses (Chittenden, \& Ritchie, 2011). A low quality of work life can lead to feelings of frustration, inadequacy, and feelings of guilt. If it continues, it can lead to an incident of turnover for nurses (Almalki et al., 2017). The very low quality of nursing work life in hospitals will result in high nurse absenteeism and turnover.

The occurrence of turnover begins with the emergence of a desire to change jobs (turnover intention) by employees. This desire arises when employees are still working at the company and is influenced by many factors, including the quality of the work of nurses as described above. According to Zeffane (2003) turnover intention is the tendency or intention of employees to stop working from their jobs. The desire to leave an organization is generally preceded by employee intentions which are triggered, among others, by employee dissatisfaction with work and low employee commitment to bind themselves to the organization (Jimad, 2011).

Based on data obtained from RSIA Ananda, it is known that the nurse turnover rate in 2018 was $7.3 \%$, and $10.3 \%$ in 2019. In another hospital, namely RSKD Mother and Children Pertiwi, the nurse turnover rate in 2017 was $11.3 \%$, , in 2018 it was $9.4 \%$, and in 2019 it was $4.8 \%$.

The high turnover of nurses at RSIA Ananda from year to year needs to be examined by the problems that lie behind it. Meanwhile, if we look at the number of nurses' turnover in RSKD Mother and Children Pertiwi which is decreasing year by year, it is also necessary to know the factors behind it. The work quality factor is one of the factors that can lead to the desire to quit or turnover intentions from nurses. Based on the above background, the problem in this study is how the relationship between the quality of work of nurses and turnover intentions of nurses at RSIA Ananda and RSKD Mother and Children Pertiwi, and tries to explore what dimensions have the most influence on turnover intentions of nurses at RSIA Ananda and RSKD. Mother and the Motherland and see how the dimensions of the quality of nursing work life compare to the turnover intention of the two hospitals.

\section{Methods}

This research was conducted at RSIA Ananda and RSKDIA Pertiwi. The type of research conducted is quantitative research using an observational study with a Cross Sectional Study approach. The population in this study were all nurses who worked at RSIA Ananda and RSKDIA Pertiwi. The sample in this study were nurses who worked at RSIA Ananda as many as 72 nurses who were representatives of private hospital nurses and nurses who worked at RSKD Mother and Children Pertiwi as many as 70 nurses who were representatives of the population of government hospital nurses. so the total number of samples in this study were 108 nurses.

The instrument used in data collection is a questionnaire. There are four independent variables which are dimensions of Quality of Nursing Work Life, namely work life/homelife dimensions, work design dimensions, work context dimensions and work world dimensions. The dependent variable is turnover intention. The measurement used in the data processing process is to use a Likert scale, where respondents state their level of agreement or disagreement regarding various objects regarding the behavior of objects, people, or events. The data analysis technique used is univariate analysis, bivariate analysis and multivariate analysis with logistic regression test. 
Univariate analysis was conducted to obtain an overview of the research problem by describing each variable used in the study and the characteristics of the respondents. Bivariate analysis was conducted to see the relationship between two variables, namely between the independent variable and the dependent variable. The multivariate analysis used is a logistic regression test which analyzes one or several independent variables with a dependent variable, and sees which independent variables are most related to the dependent variable.

\section{Results and Discussion}

\section{Characteristics of respondents}

Table 1. Distribution of Respondents Based on Characteristics of Respondents at RSIA Ananda in 2021

\begin{tabular}{|c|c|c|c|c|c|}
\hline No. & \multicolumn{2}{|c|}{ Characteristics of Respondents } & $\begin{array}{l}\text { Number } \\
\text { (n) }\end{array}$ & $\begin{array}{c}\text { Percentage( } \\
\%)\end{array}$ & Total \\
\hline \multirow{3}{*}{1.} & \multirow{3}{*}{ Age } & 20-35 years & 66 & 91.7 & \multirow{3}{*}{72} \\
\hline & & $36-45$ years & 6 & 8.3 & \\
\hline & & $>45$ years old & 0 & 0 & \\
\hline \multirow{2}{*}{2.} & \multirow{2}{*}{ Gender } & Man & 3 & 4,2 & \multirow{2}{*}{72} \\
\hline & & Woman & 69 & 95.8 & \\
\hline \multirow{4}{*}{3.} & \multirow{4}{*}{ Working Time } & $1-2$ years & 47 & 65.3 & \multirow{4}{*}{72} \\
\hline & & 3-4 years & 17 & 23.6 & \\
\hline & & $5-6$ years & 1 & 1.4 & \\
\hline & & $>7$ years & 7 & 0 & \\
\hline \multirow{4}{*}{4.} & \multirow{4}{*}{$\begin{array}{l}\text { The Last } \\
\text { Education }\end{array}$} & SLTA/Equivalent & 0 & 0 & \multirow{4}{*}{72} \\
\hline & & Diploma & 40 & 55.6 & \\
\hline & & $\mathrm{S} 1$ & 12 & 16.7 & \\
\hline & & Other & 20 & 27.8 & \\
\hline \multirow{3}{*}{5.} & \multirow{3}{*}{ Staffing Status } & PNS & 0 & 0 & \multirow{3}{*}{72} \\
\hline & & Non PNS & 72 & 100 & \\
\hline & & Other & 0 & 0 & \\
\hline
\end{tabular}

Table 1 shows the frequency distribution based on the characteristics of the sample at the research site at RSIA Ananda. Characteristics of respondents based on age the most is the age group of 20-35 years as many as 66 people $(91.7 \%)$. The characteristics of respondents based on gender were mostly female respondents, namely 69 people $(95.8 \%)$. The characteristics of respondents based on years of service are mostly respondents with 1-2 years of service, namely 47 people $(65.3 \%)$. Characteristics of respondents based on the most recent education are respondents with Diploma education as many as 40 people (55.6\%). Characteristics of respondents based on employment status are respondents with non-PNS female employment status as many as 72 people $(100 \%)$.

Table 2. Distribution of Respondents Based on Characteristics of Respondents at RSKDIA Pertiwi in 2021

\begin{tabular}{|c|c|c|c|c|c|}
\hline No. & \multicolumn{2}{|c|}{ Characteristics of Respondents } & $\begin{array}{c}\text { Number } \\
(\mathbf{n})\end{array}$ & $\begin{array}{c}\text { Percentage } \\
(\mathbf{\%})\end{array}$ & Total \\
\hline \multirow{2}{*}{1.} & \multirow{2}{*}{ Age } & $20-35$ years & 21 & 30,0 & \multirow{2}{*}{70} \\
\cline { 2 - 5 } & & $36-45$ years & 40 & 57,1 & \\
\hline
\end{tabular}

Copyright (0) 2022, Journal of Asian Multicultural Research for Medical and Health Science Study, Under the license CC BY-SA 4.0 


\begin{tabular}{|c|c|c|c|c|c|}
\hline & & $>45$ years old & 9 & 12,9 & \\
\hline \multirow{2}{*}{2.} & \multirow{2}{*}{ Gender } & Man & 0 & 0 & \multirow{2}{*}{70} \\
\hline & & Woman & 70 & 100 & \\
\hline \multirow{4}{*}{3.} & \multirow{4}{*}{ Working Time } & $1-2$ years & 0 & 0 & \multirow{4}{*}{70} \\
\hline & & 3-4 years & 57 & 81,4 & \\
\hline & & $5-6$ years & 13 & 18,6 & \\
\hline & & $>6$ years & 0 & 0 & \\
\hline \multirow{4}{*}{4.} & \multirow{4}{*}{$\begin{array}{l}\text { The Last } \\
\text { Education }\end{array}$} & SLTA/Equivalent & 0 & 0 & \multirow{4}{*}{70} \\
\hline & & Diploma & 56 & 81,4 & \\
\hline & & S1 & 14 & 18,6 & \\
\hline & & Other & 0 & 0 & \\
\hline \multirow{3}{*}{5.} & \multirow{3}{*}{ Staffing Status } & PNS & 36 & 51,4 & \multirow{3}{*}{70} \\
\hline & & Non PNS & 34 & 48,6 & \\
\hline & & Other & 0 & 0 & \\
\hline
\end{tabular}

Table 2 shows the frequency distribution based on the characteristics of the sample in the research location at RSKDIA Pertwi. Characteristics of respondents based on age the most is the age group 35-45 years, namely as many as 40 people $(57.1 \%)$. Characteristics of respondents based on gender the most are respondents with female sex as many as 70 people $(100 \%)$. Characteristics of respondents based on years of service the most are respondents with 3-4 years of service, as many as 57 people (81.4\%). Characteristics of respondents based on the most recent education are respondents with Diploma education as many as 56 people (80\%). Characteristics of respondents based on employment status the most are respondents with civil servant status as many as 36 people $(51.4 \%)$

\section{Univariate Analysis}

Table 3. Distribution of Respondents by Worklife/Homelife Dimension in 2021

\begin{tabular}{|c|c|c|c|c|}
\hline \multirow{2}{*}{$\begin{array}{c}\text { Worklife/Home Life } \\
\text { Dimension }\end{array}$} & \multicolumn{2}{|c|}{$\begin{array}{c}\text { RSIA } \\
\text { Ananda }\end{array}$} & \multicolumn{2}{c|}{$\begin{array}{c}\text { Rskd Mother and Children } \\
\text { Earth }\end{array}$} \\
\cline { 2 - 5 } & Sum & $\mathbf{( \% )}$ & Sum & $(\%)$ \\
\hline Good & 54 & 75 & 60 & 85,7 \\
\hline Bad & 18 & 25 & 10 & 14,3 \\
\hline Total & $\mathbf{7 2}$ & $\mathbf{1 0 0 , 0}$ & $\mathbf{7 0}$ & $\mathbf{1 0 0}$ \\
\hline
\end{tabular}

Table 3 explains the percentage of respondents' assessments of the worklife/homelife dimension research variables that of the 72 respondents at RSIA Ananda, 54 respondents $(75 \%)$ with the worklife/homelife dimension were classified as good and 18 respondents (25\%) with the worklife/homelife dimensions classified as poor. Meanwhile, in RSKD Mother and Children Pertiwi of 70 respondents, 60 respondents $(85.7 \%)$ with worklife/homelife dimensions were classified as good and 10 respondents (14.3\%) with worklife/homelife dimensions were classified as poor.

Table 4. Distribution of Respondents Based on Work Design Dimensions in 2021

\begin{tabular}{|c|c|c|c|c|}
\hline \multirow{2}{*}{$\begin{array}{c}\text { Work Design } \\
\text { Dimension }\end{array}$} & \multicolumn{2}{|c|}{$\begin{array}{c}\text { RSIA } \\
\text { Ananda }\end{array}$} & \multicolumn{2}{c|}{$\begin{array}{c}\text { Mother and Child Hospital } \\
\text { Earth }\end{array}$} \\
\cline { 2 - 5 } & Sum & $(\boldsymbol{\%})$ & Sum & $(\%)$ \\
\hline Good & 49 & 68,1 & 56 & 80 \\
\hline
\end{tabular}

Copyright (O) 2022, Journal of Asian Multicultural Research for Medical and Health Science Study, Under the license CC BY-SA 4.0 


\begin{tabular}{|c|c|c|c|c|}
\hline Bad & 23 & 31,9 & 14 & 20 \\
\hline Total & $\mathbf{7 2}$ & $\mathbf{1 0 0 , 0}$ & $\mathbf{7 0}$ & $\mathbf{1 0 0}$ \\
\hline
\end{tabular}

Table 4 explains the percentage of respondents' assessments of the work design dimension research variable that out of 72 respondents at RSIA Ananda, as many as 49 respondents $(68.1 \%)$ with the work design dimension classified as good and 23 respondents (31.9\%) with the work design dimension classified as poor. . Meanwhile, in RSKD Mother and Child, from 70 respondents, as many as 56 respondents $(80 \%)$ with work design dimensions classified as good and 20 respondents (20\%) with work design dimensions classified as poor.

Table 5. Distribution of Respondents Based on Work Context Dimensions in 2021

\begin{tabular}{|c|c|c|c|c|}
\hline \multirow{2}{*}{$\begin{array}{c}\text { Work Context } \\
\text { Dimension }\end{array}$} & \multicolumn{2}{|c|}{$\begin{array}{c}\text { RSIA } \\
\text { Ananda }\end{array}$} & \multicolumn{2}{c|}{$\begin{array}{c}\text { Mother and Child Hospital } \\
\text { Earth }\end{array}$} \\
\cline { 2 - 5 } & Sum & $\mathbf{( \% )}$ & Sum & $(\%)$ \\
\hline Good & 54 & 80,6 & 40 & 57,1 \\
\hline Bad & 14 & 19,4 & 30 & 42,9 \\
\hline Total & $\mathbf{7 2}$ & $\mathbf{1 0 0 , 0}$ & $\mathbf{7 0}$ & $\mathbf{1 0 0}$ \\
\hline
\end{tabular}

Table 5 explains the percentage of respondents' assessments of the work context dimension research variable that of 72 respondents at RSIA Ananda, as many as 51 respondents $(80.2 \%)$ with the work context dimension classified as good and 14 respondents $(19.4 \%)$ with the work context dimension classified as poor. . Meanwhile, in RSKD Mother and Children Pertiwi, from 70 respondents, 40 respondents $(57.1 \%)$ with a work context dimension classified as good and 30 respondents $(42.9 \%)$ with a work context dimension classified as poor.

Table 6. Distribution of Respondents by Work World Dimension in 2021

\begin{tabular}{|c|c|c|c|c|}
\hline \multirow{2}{*}{$\begin{array}{c}\text { Work World } \\
\text { Dimension }\end{array}$} & \multicolumn{2}{|c|}{$\begin{array}{c}\text { RSIA } \\
\text { Ananda }\end{array}$} & \multicolumn{2}{c|}{$\begin{array}{c}\text { Mother and Child Hospital } \\
\text { Earth }\end{array}$} \\
\cline { 2 - 5 } & Sum & $(\boldsymbol{\%})$ & Sum & $(\%)$ \\
\hline Good & 49 & 68,1 & 46 & 65,7 \\
\hline Bad & 23 & 31,9 & 24 & 34,3 \\
\hline Total & $\mathbf{7 2}$ & $\mathbf{1 0 0 , 0}$ & $\mathbf{7 0}$ & $\mathbf{1 0 0}$ \\
\hline
\end{tabular}

Table 6 explains the percentage of respondents' assessments of the work world dimension research variable that out of 72 respondents at RSIA Ananda, 49 respondents (68.1\%) with a work world dimension classified as good and 23 respondents $(31.9 \%)$ with a work world dimension classified as poor. . While in RSKD Mother and Children Pertiwi of 70 respondents, 46 respondents $(65.7 \%)$ with a work world dimension classified as good and 24 respondents $(34.3 \%)$ with a work world dimension classified as bad.

Table 7. Distribution of Respondents Based on Turnover Intention in 2021

\begin{tabular}{|c|c|c|c|c|}
\hline \multirow{2}{*}{$\begin{array}{c}\text { Turnover } \\
\text { Intention }\end{array}$} & \multicolumn{2}{|c|}{$\begin{array}{c}\text { RSIA } \\
\text { Ananda }\end{array}$} & \multicolumn{2}{c|}{$\begin{array}{c}\text { Mother and Child Hospital } \\
\text { Earth }\end{array}$} \\
\cline { 2 - 5 } & Sum & $\mathbf{( \% )}$ & Sum & $(\%)$ \\
\hline Tall & 20 & 27,8 & 7 & 10,0 \\
\hline Low & 72 & 72,2 & 63 & 90,0 \\
\hline Total & $\mathbf{7 2}$ & $\mathbf{1 0 0 , 0}$ & $\mathbf{7 0}$ & $\mathbf{1 0 0}$ \\
\hline
\end{tabular}

Table 7 explains the percentage of respondents' assessment of the turnover intention research variable that of 72 respondents at RSIA Ananda, as many as 20 respondents (27.8\%) with high turnover intention and 52 respondents $(72.2 \%)$ with low turnover intention. RSKD Mother and

Copyright $@$ (2022, Journal of Asian Multicultural Research for Medical and Health Science Study, Under the license CC BY-SA 4.0 
Children Pertiwi of 70 respondents, 7 respondents (10\%) with high turnover intention and 63 respondents $(90 \%)$ with low turnover intention.

\section{Bivariate Analysis}

Table 8 shows the relationship between the worklife/homelife dimension variables on turnover intention, the statistical test results obtained $p$ value $=0.239$, because the $p>\alpha=0.239>0.05$ then $\mathrm{Ho}$ is accepted, this means that there is no statistically significant effect on worklife/homelife. dimension to turnover intention at RSIA Ananda. The relationship between worklife/homelife dimension variables on turnover intention, the results of statistical tests obtained $p$ value $=0.055$, because $p>\alpha=0.055<0.05$ then Ho is accepted, this means that there is no significant effect Worklife/homelife dimension statistics on turnover intention in RSKD Mother and Children Pertiwi. The relationship of the work design dimension variable to turnover intention, the results of statistical tests obtained $p$ value $=0.260$, because the value of $\mathrm{p}>=0.260>0.05$ then Ho is accepted, this means that there is no statistically significant effect of work design dimension on turnover intention in RSIA Ananda. The relationship of the work design dimension variable to turnover intention, the results of statistical tests obtained a value of $p=1,000$, because the value of $p>\alpha=1,000>0.05$ then Ho is accepted, this means that there is no statistically significant effect of the work design dimension on turnover intention in RSKD Mother and Child Motherland.

The relationship of the work context dimension variable to turnover intention, the results of statistical tests obtained a value of $p=0.093$, because the value of $p>\alpha=0.093<0.05$ then Ho is accepted, this means that there is no statistically significant effect of the work context dimension on turnover intention in RSIA Ananda. The relationship of the work context dimension variable to turnover intention, the results of statistical tests obtained a value of $\mathrm{p}=$ 1,000 , because the value of $\mathrm{p}>\alpha=1,000>0.05$ then Ho is accepted, this means that there is no statistically significant effect of the work context dimension on turnover intention in RSKD Mother and Child Motherland. The relationship of the work world dimension variable to turnover intention, the results of statistical tests obtained a value of $p=0.016$, because the value of $p<\alpha=0.016<0.05$ then Ho is rejected, this means that there is a statistically significant effect of work world dimension on turnover intention at RSIA Ananda. The relationship of the work world dimension variable to turnover intention, the results of statistical tests obtained a value of $p=0.684$, because the value of $p>\alpha=0.684<0.05$ then Ho is accepted, this means that there is no statistically significant effect of work world dimension on turnover intention in RSKD Mother and Child Motherland.

Table 8. Comparison of Sig. to Test the Effect of Quality of Nursing Work Life Dimensional Variables on Turnover Intention at RSIA Ananda and RSKDIA Pertiwi

\begin{tabular}{|c|c|c|c|}
\hline \multirow{2}{*}{ No. } & Variables & \multicolumn{2}{|c|}{ Sig. } \\
\cline { 3 - 4 } & & RSIA Ananda & RSKDIA Pertiwi \\
\hline 1. & Worklife/homelife $\rightarrow$ Turnover Intention & 0,239 & 0,055 \\
\hline 2. & Work Design $\rightarrow$ Turnover Intention & 0,260 & 1,000 \\
\hline 3. & Work Context $\rightarrow$ Turnover Intention & 0.093 & 1,000 \\
\hline $\mathbf{4}$ & Work World $\rightarrow$ Turnover Intention & 0.016 & 0,684 \\
\hline
\end{tabular}




\section{Multivariate Analysis}

Table 9. Effect of Worklife, Work Design, Work Context, and Work World Variables on Turnover Intention at RSIA Ananda in 2021

\begin{tabular}{|c|c|c|c|c|c|c|c|c|}
\hline & $\mathbf{B}$ & $\mathbf{S . E}$ & $\begin{array}{c}\text { Standardized } \\
\text { Coefficients Beta }\end{array}$ & $\mathbf{t}$ & Sig. & $\begin{array}{c}\text { 95\% C.I. for } \\
\mathbf{E x P}(\mathbf{B})\end{array}$ \\
\cline { 2 - 8 } & $\begin{array}{c}\text { Category Work Life } \\
\text { Dimension }\end{array}$ & -.157 & .265 & -.151 & 4.720 & .202 & .923 & 1.084 \\
\cline { 2 - 8 } Step & $\begin{array}{c}\text { Kategori Work Design } \\
\text { Dimension }\end{array}$ & .100 & .121 & .104 & - & .290 & .960 & 1.041 \\
\cline { 2 - 9 } & $\begin{array}{c}\text { Category Work Context } \\
\text { Dimension }\end{array}$ & .200 & .111 & .177 & .900 & .154 & .848 & 1.180 \\
\cline { 2 - 9 } & $\begin{array}{c}\text { Category Work World } \\
\text { Dimension }\end{array}$ & .205 & .139 & -.227 & 1.442 & .047 & .890 & 1.122 \\
\cline { 2 - 9 } & Constant & 1.252 & .265 & & 4.207 & .000 & & \\
\hline
\end{tabular}

Table 9 explains how closely the direct and indirect effects between variables are, namely between the dimension variables of Quality of Working Life and Turnover Intention variable. Variables in the equation Constant $(\mathrm{Bo})=1.252$, logistic regression coefficient for the independent variable worklife dimension $(\mathrm{B} 1)=-0.157$, work design dimension $(\mathrm{B} 2)=0.100$, work context dimension $(B 3)=0.200$, and work world dimension $(B 4)=0.205$. The p value of each independent variable work life dimension is $p=0.202$, work design dimension is $p=$ 0.371 , work context dimension is $\mathrm{p}=0.154$ and work world dimension is $\mathrm{p}=0.047$. By paying attention to the $\mathrm{p}$ value, only the work world dimension variable has a $\mathrm{p}$ value $<0.05$. This means that only the work world dimension variable has an influence on turnover intention at RSIA Ananda.

Table 10. Influence of Worklife, Work Design, Work Context, and Work World Variables on Turnover Intention in RSKD for children and Motherland in 2021

\begin{tabular}{|c|c|c|c|c|c|c|c|c|}
\hline \multirow{6}{*}{ Step } & & \multirow{2}{*}{$\begin{array}{c}\mathbf{B} \\
-.237\end{array}$} & \multirow{2}{*}{$\begin{array}{l}\text { S.E } \\
.103\end{array}$} & \multirow{2}{*}{$\begin{array}{c}\begin{array}{c}\text { Standardized } \\
\text { Coefficients Beta }\end{array} \\
-.277 \\
\end{array}$} & \multirow{2}{*}{$\begin{array}{c}\mathbf{t} \\
-.277\end{array}$} & \multirow{2}{*}{$\begin{array}{l}\text { Sig. } \\
.025\end{array}$} & \multicolumn{2}{|c|}{$\begin{array}{l}95 \% \text { C.I. } \\
\text { for } \operatorname{ExP}(B)\end{array}$} \\
\hline & $\begin{array}{c}\text { Category Work Life } \\
\text { Dimension }\end{array}$ & & & & & & .973 & 1.028 \\
\hline & $\begin{array}{c}\text { Category Work } \\
\text { Design Dimension }\end{array}$ & .058 & .090 & .078 & .078 & .520 & .980 & 1.019 \\
\hline & $\begin{array}{c}\text { Category Work } \\
\text { Context Dimension }\end{array}$ & .011 & .074 & .018 & .018 & .881 & .946 & 1.057 \\
\hline & $\begin{array}{c}\text { Category Work World } \\
\text { Dimension }\end{array}$ & -.021 & .078 & -.034 & -.034 & .784 & $\begin{array}{c}- \\
.030 \\
\end{array}$ & 1.075 \\
\hline & Constant & 2.114 & .189 & & 11.174 & .000 & & \\
\hline
\end{tabular}

Table 10 explains how close the direct and indirect effects are between variables, namely between the dimension variables of Quality of Working Life and Turnover Intention variable. Variables in the equation Constant $(\mathrm{Bo})=2.144$, logistic regression coefficient value for the independent variable worklife dimension $(\mathrm{B} 1)=-0.237$, work design dimension $(\mathrm{B} 2)=0.058$, work context dimension $(B 3)=0.011$, and work world dimension $(B 4)=-0.021$. The $p$ value of each independent variable work life dimension is $\mathrm{p}=0.025$, work design dimension is $\mathrm{p}=$ 0.520 , the work context dimension is $p=0.881$ and the work world dimension is $p=0.784$. By paying attention to the $\mathrm{p}$ value, only the work life dimension variable has a $\mathrm{p}$ value $<0.05$. This 
means that only the work life dimension variable has an influence on turnover intention in RSKD Mother and Children Pertiwi Makassar.

\section{The Effect of Quality Nursing Worklife Dimensions Worklife/Homelife on Turnover Intention}

Quality of work life is a person's perception of the extent to which they are satisfied with the fulfillment of personal and work needs through work experience in order to achieve the goals of an organization (Sirin \& Sokmen, 2015).

Quality of work life of nurses is a comprehensive concept regarding the interaction between nurses and their work environment (Fu et al., 2015). Quality of work life of nurses is a picture of nurses' perceptions regarding the fulfillment of personal needs through work experience in the organization accompanied by efforts to achieve organizational goals. Quality of work life of nurses focuses on providing opportunities for nurses to contribute actively to the organization where they work. Quality of work life of nurses is used to describe the interactions between nurses and their work and family lives, the context of the nurse's work, relationships with the world of work, and aspects of work that affect quality of patient care (Suresh, 2013).

Respondents in this study were dominated by nurses who had a good work life/home life, both from RSIA Ananda and RSKD Mother and Children Pertiwi. A total of 54 respondents or 75\% of respondents at RSIA Ananda have a good work life/homelife. Meanwhile, for the Mother and Child Mother and Child Health Hospital (RSKD) the worklife/homelife was more, namely $85.7 \%$ or as many as 60 respondents. Work life dimensions include work commitments, policies regarding vacation schedules. Home life dimensions include the role of nurses in the home (as mother/father), daughter (care for elderly parents), and spouse (family needs, available energy). Setting working hours is related to nurse satisfaction at work so that it affects the increase in nurses to leave or enter work (Fibriansari, 2017).

Based on the results of statistical analysis conducted, it is known that the quality of nursing work life in the worklife/home life dimension has no effect on turnover intention in both RSIA Ananda and RSKD Mother and Children Pertiwi with $\mathrm{p}>\alpha=0.239>0.05$ for RSIA Ananda and $\mathrm{p}>\alpha=0.055>0.05$ for RSKD Mother and Child Motherland.

This is not in line with the research of Almalki et al. (2012) suggested that the quality of work life has a very significant relationship with turnover intention. In this study, respondents were influenced by characteristic factors. Judging from the description of the characteristics of nurse respondents at RSIA Ananda and RSKD Mother and Children Pertiwi, the respondents were dominated by female nurses. In the cross table it can be seen that male nurses have a higher turnover intention than female nurses, namely 28.6\% According to (Robbins \& Judge, 2012) female nurses have a higher turnover rate than men, where women have two big roles at once both as a housewife and as a career woman. This is included in the QNWL dimension component, namely work life-home life which includes work-life balance at work and at home (Brooks \& Anderson, 2005).

RSIA Ananda has a lower percentage than RSKD Mother and Children Pertiwi. The results showed that of the respondents for the statement "I am able to balance work and family needs" the percentage of respondents who agreed was 32\% for RSIA Ananda and 37.1\% for RSKD Mother and Children Pertiwi. This supports the results discussed above that the RSKD Mother and Children Pertiwi in the worklife/homelife dimension is better than RSIA Ananda. In contrast to the results of the study (Hemanathan et al., 2017) which said that there was an effect of work-home life on the performance of nurses, it was reported that most nurses felt tired 
because of the multitasking they had to do at home and at work. This is similar to the study findings where $58 \%$ of nurses stated that they were unable to balance work and family.

The limited time that a person has, namely the time used for work often results in limited time for family, tension in a role which ultimately affects the performance of other roles so that a balancing of roles in work and family is needed to achieve satisfaction. Work family conflict is associated with decreased job satisfaction, low family life adjustment, decreased career and family satisfaction and increased life pressure. The results showed that work-family conflict had a positive effect on turnover intention. This means that the high work-family conflict felt by employees can affect the desire to leave the company, so the higher the work-family conflict, the higher the employee's perceived turnover intention.

This is in line with role theory which states that conflict occurs when there are two or more pressures that take place simultaneously. The results of research conducted by Paramitha and Subudi (2017) obtained the value of Sig. $t$ is 0.000 with a beta coefficient of 0.211 . Value of Sig. t $0.000<0.05$ means that work-family conflict has a significant positive effect on turnover intention.

Based on the research conducted, it can be seen that neither RSIA Ananda nor RSKD Mother and Children Pertiwi had a significant effect on turnover intention from the dimension of women's life/home life. This happens because turnover intention has many variables that influence it.

\section{The Influence of Quality Nursing Worklife Dimensions of Work Design on Turnover Intention}

Respondents in this study were dominated by nurses who had a good work design category. Work design includes the composition or nursing workload and describes the work actually done by nurses. This dimension includes workload, job satisfaction, the need for assistance at work, doing non-nursing work, staffing, work motivation (Brooks \& Anderson, 2005).

The results showed that there was no direct influence between the quality of nursing work life, work design dimensions, on the turnover intention of nurses at RSIA Ananda and RSKD Mother and Children Pertiwi with $p>\alpha=0.260>0.05$ for RSIA Ananda and $p>\alpha=1,000>0.005$ for RSKD Mother and Child Motherland.

The results of this study are relevant to research (Kaddourah et al., 2018) that statistically correlation shows no significant relationship and is relevant to research (Afif, 2015) that job satisfaction does not have a significant relationship with turnover intention, but differs in the results of the study (Almalki et al., 2012) suggested that the quality of work life has a very significant relationship with turnover intention.

The imbalance of workload with the achievements obtained can affect the thoughts or intentions of nurses for turnover in addition to the value or level of quality of work life of nurses already in the good category, but nurses already have autonomy in making decisions regarding patient care in accordance with nursing care. Autonomy opportunities for nurses are able to provide knowledge, skills and attitudes of nurses to be able to be professionally responsible for their work (Fardiana, 2018).

The results showed that from 72 respondents from RSIA Ananda there were $46.3 \%$ nurses who said they did not agree with the statement "The workload is too heavy" while another $30.6 \%$ said they did not agree with the statement. Research at RSKD Mother and Children Pertiwi also showed results that were not much different, as many as $42.9 \%$ said they did not agree with 70 nurses and $21.4 \%$ said they did not agree. 
Based on the statement above, it can be said that the workload between RSIA Ananda and RSKD Mother and Children Pertiwi is good. This is supported by the characteristics indicated by another statement, namely, "Many nurses perform non-nursing tasks" from 72 respondents at RSIA Ananda as much as $55.6 \%$ stated that they did not agree. Meanwhile, for the Mother and Child Mother and Child Hospital (RSKD) as many as $82.3 \%$ of the 70 nurses said they did not agree with the statement. This can happen because both at RSIA Ananda and at RSKD Mother and Children Pertiwi both get quality assistance from health cadres so that the workload given to nurses is in accordance with the rules and has a good work design seen from the existing workload. The results showed that $68.1 \%$ of the 72 respondents of RSIA Ananda had good work design dimensions while the rest thought they were not good. The research conducted at RSKD Mother and Children Pertiwi obtained work design dimensions from 70 respondents that $80 \%$ had a good work design.

\section{The Effect of Quality of Nursing Worklife Dimension of Work Context on Turnover Intention}

Quality of work life of nurses is a term for the balance of personal and professional life which is a continuous effort for most health workers, including nurses (Chittenden, \& Ritchie, 2011).

Based on the results of statistical analysis, it is known that the quality of nursing work life in the work context dimension has no effect on turnover intention in both RSIA Ananda and RSKD Mother and Children Pertiwi with $\mathrm{p}>\alpha=0.093>0.05$ for RSIA Ananda and $\mathrm{p}$-value> $=1,000>0.05$ for RSKD Mother and Children Pertiwi.

Based on research from Prihastuty (2013) states that the quality of a nurse's work life can be seen from four dimensions, one of which is the work context where if it is not balanced it will directly affect the employee's desire to move (turnover intention).

Quality of work life (quality work life) is part of the quality of life (quality of life) that is influenced by his work, in a broader sense that quality work life is the way an employee evaluates the work in his life. Quality of work life is influenced by a person's satisfaction with his work, family life, recreational activities, social life, financial status, including the work environment such as; non-work life, life as a whole, personal happiness and well-being of a personal nature.

Based on the statement of respondents' answers regarding the work context, it is known that the communication that exists between nurses and leaders, nurses and other health workers, and nurses and doctors has been well established at RSIA Ananda and RSKD Mother and Children Pertiwi. Good communication and relationships also affect a nurse at work. Good communication and relationships with colleagues is one of the requirements to produce effective, creative, and quality output in the organization (Kaswan, 2012).

In another study by (Firqotul, 2015) said that good relations with colleagues have a relationship with nurse performance, the higher the level of satisfaction of nurses in co-worker relationships shows better performance and affects lower turnover.

\section{The Effect of Quality of Nursing Worklife Dimension of Work World on Turnover Intention}

Nurses as the largest health workers should have a good quality of work life so that they can provide quality services to patients (Moradi et al., 2014). Quality of work life is a perception or assessment of all dimensions that affect the quality of work life related to experience at work and in order to achieve organizational goals (Husnawati, 2006). 
Based on the results of statistical analysis, it is known that the quality of nursing work life on the work world dimension has an influence on turnover intention at RSIA Ananda with a value of $\mathrm{p}<\alpha=0.016<0.05$ and has no effect on the quality of nursing work life on the work world dimension with turnover intention. in RSKD Mother and Child Motherland with a value of $\mathrm{p}>\alpha=0.684>0.05$.

Research from Ardiana et al (2020) states that the quality of work in the context of the work world is about payments given by companies where according to most of the payments given by respondents are not entirely fulfilled. The work and duties of each employee make them tired, there is no tolerance for time when employees are sick so they cannot enter, therefore respondents think that some of them will feel tired and intend to leave work and look for a more decent job in terms of salary. and working hours.

The results of Kaddourah et al (2018) research that the correlation between QNWL and turnover statistically shows no significant and relevant relationship with Afif (2015) research that the quality of work life does not have a significant relationship with turnover intention, but differs from the results of Almalki et al's research. al. (2012) suggested that the quality of work life has a very significant relationship with turnover intention.

Research from Hamzah et al (2011) states that another factor that also affects nurses' turnover intentions is that nurses feel that the compensation they receive is not in accordance with job market conditions and nurses feel they are able to get the same job elsewhere with the same salary and benefits. This can affect the emergence of turnover intentions in nurses. Adequacy of salary or compensation is one of the factors that indicate the occurrence of turnover intention. During the Covid-19 pandemic, nurse incentives were often not on time and did not go down one hundred percent.

According to Lum et al., (1998) salary satisfaction can be interpreted that a person will be satisfied with his salary when the perception of salary and what they get is in accordance with what is expected. Several studies identified aspects of satisfaction that were found to be associated with an individual's desire to leave the organization including satisfaction with wages and promotions. Murray (1994) in his research on career, worker and nursing staff satisfaction in hospitals found $10 \%$ of nurses were satisfied with their salary and $46 \%$ were not satisfied.

\section{The Most Influential Variable Dimensions on the Quality of Nursing Work Life on Turnover Intention at RSIA Ananda and RSDK Mother and Children Pertiwi}

Quality of Nurse Work Life (QNWL) has a very important meaning for hospital organizations. There are four dimensions that influence and as a factor of QNWL, namely; work life -home life balance (work life and family life) which includes work-life balance at work and home life, remaining energy, organizational policies at work, setting working hours, work design dimensions (work design) which includes job satisfaction, autonomy, workload, work context dimensions (work context) which includes the impact of the work environment on nurses, communication, co-workers, security, and supervision, and work world dimensions which include the image of the nursing profession in the eyes of the public, confidence, adequacy salary, desire to change jobs (Brooks \& Anderson, 2005).

Based on the analytical results that have been carried out, it is known that the work world dimension variable has the most influence on turnover intention at RSIA Ananda, while the work life dimension variable has the most influence on turnover intention at RSKD Mother and Children Pertiwi Makassar. 
A study in China by Zhao et al. (2012) stated in his research that the quality of work life, job embeddedness and affective commitment affect turnover intention. This study was conducted on nurses at a hospital in China, the results showed that a high quality work life (QWL) would increase job embeddedness and affective commitment, thereby reducing turnover intention.

Other research states that the quality of work life (quality work life), job satisfaction and emotional exhaustion experienced by nurses because of their workload causes an increase in the desire to leave work (turnover intention) (Fitri, 2013). Several other studies such as Huang et al., (2007), Almalki et al., (2012) and Lee et al., (2013) show the same thing that quality work life (QWL) can affect turnover intention (TOI).

In this study, respondents were influenced by characteristic factors. Judging from the description of the characteristics of the nurse respondents at RSIA Ananda, the respondents were dominated by nurses aged 20-35 years. In the cross table, it can be seen that nurses aged 20-35 years have a higher turnover intention rate of 28.8\%. Meanwhile, in RSKD Mother and Children Pertiwi, respondents were dominated by nurses aged 36-45 years. In the cross table, it can be seen that nurses aged 36-45 years have a turnover intention of 7.5\%.

According to Kusumaningrum \& Harsanti (2015) that turnover intentions at the age of 31-35 are higher than in other age ranges, while according to McCarthy et al. (2006) Young nurses between 21 and 35 years of age tend to show more turnover intention than older nurses. This is in line with Morsy \& Sabra (2015) that nurses aged 25-30 years who experience work dissatisfaction with the quality of work life. Nurses at an older age were more satisfied with their current job and were less likely to plan to leave or turn over. This finding is also in line with Kusumaningrum \& Harsanti (2015) that job satisfaction at age $>40$ years is higher than age $<40$ years. Old age nurses assume that because the desired expectations have been fulfilled and tend to have a good quality of work life, so that the turnover intention is lower than at a younger age. Researchers assume that nurses in early adulthood are more prone to turnover intentions where at that age nurses still have high expectations for their work, and are at an early stage in adjusting to the work environment, causing nurses to think about moving or turnover.

In this study, respondents were influenced by characteristic factors. Judging from the description of the characteristics of nurse respondents at RSIA Ananda and RSKD Mother and Children Pertiwi, the respondents were dominated by female nurses. In the cross table, it can be seen that female nurses have a higher turnover intention in RSIA Ananda and RSKD Mother and Children Pertiwi with $33.1 \%$ and $22.9 \%$ respectively. According to Robbins \& Judge (2012) female nurses have a higher turnover rate than men, where women have two major roles at once both as a housewife and as a career woman. This is included in the QNWL dimension component, namely work life-home life which includes work-life balance at work and at home (Brooks \& Anderson, 2005). It is different from the research of Kusumaningrum \& Harsanti (2015) that male nurses have higher turnover intentions. The researcher assumes that the work life or workload of male nurses and female nurses does not differ much in the provision of nursing care services, and expectations for the quality of nurses' working life while at the institution, however, female nurses are more patient and gentle.

In this study, respondents were influenced by characteristic factors. Judging from the description of the characteristics of nurse respondents at RSIA Ananda and RSKD Mother and Children Pertiwi, the respondents were dominated by nurses with a vocational education background (Diploma-3). In the cross table, it can be seen that nurses with diploma education have a turnover intention rate at RSIA Ananda and RSKD Mother and Children Pertiwi with $22.5 \%$ and $12.5 \%$ respectively. According to Arbianingsih et al. (2016) Nurses with a high 
level of education are able to solve problems clearly without being affected by the surrounding environment. In addition, nurses who have higher education have the ability to occupy a position so that there is a lower turnover intention. The high level of education reflects a person's ability to be able to solve the problems at hand. Nurses who have a higher level of education will feel bored quickly and are more willing to go out and look for a new job. Researchers assume that the level of education can influence a person's attitude in making decisions and have more skills and experience, nurses with high education tend to have high expectations of the quality of working life in institutions and can facilitate nurses in developing knowledge to increase skills, so that the management should pay more attention to the condition of nurses, because it will influence professional nurses to start thinking about changing jobs (turnover) if this problem is not followed up, so nurses who already have a lot of skills and work experience will actually quit or turn over and this can detrimental to an organization.

In this study, respondents were influenced by characteristic factors. Judging from the description of the characteristics of nurse respondents at RSIA Ananda, the respondents were dominated by nurses with 1-2 years of work. In the cross table, it can be seen that nurses with a working period of 1-2 years have a higher turnover intention, namely $31.9 \%$. Meanwhile, the description of the characteristics of nurse respondents with turnover intention in RSKD Mother and Children Pertiwi is dominated by nurses with a long working period of 3-4 years $(12.3 \%)$. According to Kusumaningrum \& Harsanti (2015) nurses who have worked for more than 20 years have a lower turnover rate than new nurses, because nurses who have worked for longer have better adaptation to the work environment than new nurses. Researchers assume that nurses with a long working period tend to have more work experience and can create a sense of loyalty to the organization, have a good quality of work life and have fulfilled job expectations.

\section{Conclusion}

The conclusion of this study is that there is no effect of the quality of nursing work life in the worklife/home life dimension on turnover intention at RSIA Ananda and RSKD Mother and Children Pertiwi, there is no effect on the quality of nursing work life in the work design dimension on turnover intention at RSIA Ananda and RSKD Mother and Children Pertiwi, there is no effect of quality of nursing work life dimension of work context dimension on turnover intention in RSIA Ananda and RSKD Mother and Children Pertiwi, there is influence of quality of nursing work life dimension of work world dimension on turnover intention at RSIA Ananda and not there is an influence of quality of nursing work life dimension of work world dimension on turnover intention in RSKD Mother and Children Pertiwi, as well as work world dimension on quality of nursing work life which most influence on turnover intention at RSIA Ananda and dimension of work life/home life on quality of nursing work life that has the most influence on turnover intention in R SKD Mother and Child Motherland.

Based on the results of the research and the conclusions that have been formulated, several suggestions or recommendations are put forward, namely, the hospital should consider adding nurse facilities to improve QNWL, especially in the work world dimension. To reduce turnover intention, pay more attention to salary satisfaction, hospitals can consider adding nurse facilities to increase QNWL, especially in the work world dimension. To reduce turnover intention should pay more attention to salary satisfaction, the results of this study are expected to hospital institutions can make research results as a solution in the consideration of service quality management to pay more attention to the condition of nurses both physically and psychologically, especially nurses who are starting to show dissatisfaction with work and find out the cause of the problem so that a solution can then be found by opening a suggestion box

Copyright $@$ 2022, Journal of Asian Multicultural Research for Medical and Health Science Study, Under the license CC BY-SA 4.0 
or communication channel to the management, and nurses must be able to evaluate the quality of their work life by identifying the fulfillment of psychological needs needed during work. This is to increase the motivation of nurses to work so that commitment to the organization will increase as well.

\section{References}

AFIF D, A. L. B. A. (2015). Faktor-Faktor Yang Berhubungan Dengan Kecenderungan Turnover Intention Perawat Di Rumah Sakit Harapan Bunda Batam Tahun 2015 (Doctoral dissertation, Upt Perpustakaan).

Almalki, M. J., FitzGerald, G., \& Clark, M. (2012). The relationship between quality of work life and turnover intention of primary health care nurses in Saudi Arabia. BMC health services research, 12(1), 1-11.

Arbianingsih, A., Hidayah, N., \& Taufiq, T. (2016). Hubungan Beban Kerja Dengan Turnover Pada Perawat Di Rumah Sakit Islam Faisal Makassar. Journal of Islamic Nursing, 1(1), 11-20.

Brooks, B. A., \& Anderson, M. A. (2005). Defining quality of nursing work life. Nursing Economics, 23(6), 319-326.

Chittenden, E. H., \& Ritchie, C. S. (2011). Work-life balancing: challenges and strategies. Journal of palliative medicine, 14(7), 870-874.

Fardiana, A. (2019). Hubungan Quality Of Nursing Work Life Dengan Kinerja Perawat Di Rsud Syarifah Ambami Rato Ebu Kabupaten Bangkalan (Doctoral dissertation, Universitas Airlangga).

Fibriansari, R. D. (2017). Pengembangan Model Empowerment terhadap Burnout Syndrome dan quality of nursing work life di RSUD Dr. Haryoto Lumajang (Doctoral dissertation, Universitas Airlangga).

Firqotul A. (2015). Penilaian Atasan Dan Teman Sejawat Terhadap Kinerja Guru Semasa Honorer dan Setelah PNS d Sekolah Menengah Pertama Negeri se Kabupaten Sleman

Fitri, N. U. (2013). Intensi untuk keluar pada perawat RSH dilihat dari Quality of working life, kepuasan kerja dan kelelahan emosi dengan kontrol kepuasan penghasilan, UGM.

Fu, X. (2015). Validation of The Chinese Version of The Quality of Nursing Work Life Scale. PLOS ONE. 10(5): 1-12.

Hamzah, A. (2011). Analisis Faktor Keinginan Pindah Kerja (Intention Turnover) Perawat Di Rumah Sakit Umum Daerah (Rsud) Kabupaten Buol Prov Insi Sulawesi Tengah (Doctoral dissertation, Tesis, Fakultas Kesehatan Masyarakat Program Studi Kajian Administrasi Rumah Sakit Depok, Universitas Indonesia).

Hemanathan, R., Prakasam, P., \& Golda, M. (2017). Quality of work life among nurses in a tertiary care hospital. JOJ Nurse Health Care, 5 (4), 1-8.

Huang, T. C., Lawler, J., \& Lei, C. Y. (2007). The effects of quality of work life on commitment and turnover intention. Social Behavior and Personality: an international journal, 35(6), 735-750.

Husnawati, A. (2006). Analisis pengaruh kualitas kehidupan kerja terhadap kinerja karyawan dengan komitmen dan kepuasan kerja sebagai intervening variabel (studi pada

Copyright $@$ (2022, Journal of Asian Multicultural Research for Medical and Health Science Study,

Under the license CC BY-SA 4.0 
Perum Pegadaian Kanwil VI Semarang). Program Pascasarjana. Magister Manajemen, UNDIP Semarang.

Kaddourah, B., Abu-Shaheen, A. K., \& Al-Tannir, M. (2018). Quality of nursing work life and turnover intention among nurses of tertiary care hospitals in Riyadh: a crosssectional survey. BMC nursing, 17(1), 1-7.

Kaswan, M. M. (2012). Manajemen sumber daya manusia untuk keunggulan bersaing organisasi. Edisi Pertama. Cetakan Pertama. Penerbit Graha Ilmu. Yogyakarta.

Kusumaningrum, D., \& Harsanti, I. (2015). Kontribusi Kepuasan Kerja Terhadap Intensi Turnover Pada Perawat Instalasi Ruang Inap. Prosiding PESAT, 6.

Lee, T. W., Ashford, S. J., Walsh, J. P., \& Mowday, R. T. (1992). Commitment propensity, organizational commitment, and voluntary turnover: A longitudinal study of organizational entry processes. Journal of management, 18(1), 15-32.

Lum, L., Kervin, J., Clark, K., Reid, F., \& Sirola, W. (1998). Explaining nursing turnover intent: job satisfaction, pay satisfaction, or organizational commitment?. Journal of Organizational Behavior: The International Journal of Industrial, Occupational and Organizational Psychology and Behavior, 19(3), 305-320.

Moradi, T., Maghaminejad, F., \& Azizi-Fini, I. (2014). Quality of working life of nurses and its related factors. Nursing and midwifery studies, 3(2).

Murray, P.R., E.J. Baron, M.A. Pfaller, F.C. Tenover, R.H. Yolken, (1994). Manual of Clinical Microbiology, Sixth Edition. ASM Press

Prihastuty, J., \& Damayanti, N. A. (2013). Model Peningkatan Quality Of Nursing Work Life Untuk Menurunkan Intention To Quit Perawat Di Rumah Sakit Premier Surabaya. JURNAL NERS, 8(2), 349-356.

Robbins, S. P., \& Judge, T. A. (2008). Perilaku organisasi edisi ke-12. Jakarta: Salemba Empat, 11.

Sirin, M., \& Sokmen, S. M. (2015). Quality of nursing work life scale: the psychometric evaluation of the Turkish version. International Journal of Caring Sciences, 8(3).

Suresh, D. (2013). Quality of Nursing Work Life among nurses working in selected government and private hospitals in Thiruvananthapuram (Doctoral dissertation, SCTIMST).

Zhao, X., Sun, T., Cao, Q., Li, C., Duan, X., Fan, L., \& Liu, Y. (2013). The impact of quality of work life on job embeddedness and affective commitment and their co-effect on turnover intention of nurses. Journal of clinical nursing, 22(5-6), 780-788. 